\title{
INVESTIGACIÓN
}

\section{Fatty acid composition of leaf lipids of some Alchemilla L. (Rosaceae) species from Northeast Anatolia (Turkey)}

\author{
By F.A. Ayaz", S. Hayirlioglu-Ayaz and O. Beyazoglu \\ Department of Biology, Karadeniz Technical University, 61080 Trabzon, Turkey, \\ Fax: 0 (462) 32531 95, E-mail: faa@osf01.ktu.edu.tr
}

\section{RESUMEN}

Composición en ácidos grasos de lípidos de hojas de Alchemilla L. (Rosaceae) del Nordeste de Anatolia (Turquía).

\begin{abstract}
Se han estudiado mediante cromatografía gaseosa la composición en ácidos grasos de los lípidos totales de hojas de 23 especies correspondientes a cinco series del género Alchemilla L. Los ácidos grasos identificados y cuantificados son C 12:0, C 14:0, C 16:0, C 18:0, C 20:0, C 22:0, C 24:0, C 26:0 y C 28:0 como saturados, y $C$ 16:1, C 18:1, C 18:2 y C 18:3 como insaturados, siendo el C 18:2 y C 18:3 los mayoritarios. El contenido más elevado de ácidos grasos se observó en $A$. hirtipedicellata $(78,34 \%)$ de la ser. Elatae, A.erytropoda $(68,74 \%)$ de la ser. Pubescentes, $A$. rizensis $(76,47 \%)$ de la ser. Sericeae, $A$. dura $(73,94 \%)$ de la ser Calycinae y $A$. psedocartalinica $(74,58 \%)$ de la ser. Vulgares. El ácido graso $C 18: 1$ se determinó en cantidades traza, mientras que los ácidos $C 20: 0, C 22: 0, C 24: 0$ y C 28:0 no se determinaron en la mayoría de estas especies. Se discuten el valor taxonómico y las implicaciones filogenéticas de los resultados.
\end{abstract}

PALABRAS-CLAVE: Acido graso - Alchemilla L. (Rosaceae) Hoja - Taxonomía - Turquía.

\section{SUMMARY}

Fatty acid composition of leaf lipids of some AlchemiIla L. (Rosaceae) species from Northeast Anatolia (Turkey)

Fatty acid composition of total leaf lipids of 23 species from five series of the genus Alchemilla $L$. was studied by GC. Fatty acids identified and quantified are C 12:0, C 14:0, C 16:0, C 18:0, C 20:0, C 22:0, C 24:0, C 26:0 and C 28:0 as saturated, and $C 16: 1, C 18: 1, C 18: 2$ and $C 18: 3$ as unsaturated with the major fatty acids $C 18: 2$ and $C 18: 3$. The highest content of fatty acid was quantified in $A$. hirtipedicellata $(78.34 \%)$ for ser. Elatae, $A$. erytropoda $(68.74 \%)$ for ser. Pubescentes, $A$. rizensis $(76.47 \%)$ for ser. Sericeae, $A$. dura $(73.94 \%)$ for ser. Calycinae and $A$. psedocartalinica $(74.58 \%)$ for ser. Vulgares. The $C 18: 1$ acid was determined in trace amounts while C 20:0, C 22:0, C 24:0 and $C 28: 0$ acids were not determined in most of these species. Taxonomic value and phylogenetic implications of results are discussed.

KEY-WORDS: Alchemilla L. (Rosaceae) - Fatty acid - Leave Taxonomy - Turkey.

\section{INTRODUCTION}

The value of fàtty acid patterns to establish systematic relationships among plants is becoming increasingly important. There are many studies in the literature dealing with phylogenetic and taxonomical aspects in relation to fatty acid composition in higher plants (Shorland, 1963; Harborne and Turner, 1984; Hegnauer, 1989).

The genus, Alchemilla L. (Rosaceae) includes more than 1000 species with a holarctic distribution. The genus also occurs on mountains of eastern Africa, from Abyssinia to the Cape of Good Hope, in Madagascar, South India, Sri Lanka and Java (Izmailow, 1981).

Alchemilla $\mathrm{L}$. is made of perennial herbs with woody rhizome (Pawlowski and Walters, 1972).

According to Pawlowski and Walters (1972) all Alchemilla species in Turkey belong to section Alchemilla including 3 subsections and 6 series with 50 species. With more recent studies the number of Alchemilla species in Turkey reached to 66 (Kalheber, 1994; Hayirlioglu and Beyazoglu, 1997; HayirliogluAyaz and Beyazoglu, 1997; Hatyirlioglu-Ayaz, 1997). The leaves and roots of some species of Alchemilla are well-known folk medicinal plants in Turkey and used as diuretic, reinforce and against constipation (A. pseudocartalinica Juz. and A. arvensis (L.) Scop) (Baytop, 1984). However, in spite of extensive taxonomical and cytological studies, chemotaxonomical data concerning Alchemilla are very scarce. This study is the first report on fatty acid composition in leaves of some Alchemilla species selected from 5 series, namely, ser. Elatae, Pubescentes, Sericeae, Calycinae and Vulgares.

In the present paper, we report a comparative study on the fatty acids composition in leaves of 23 species of Alchemilla L. distributed in Northeast Anatolia (Turkey). 


\section{MATERIALS AND METHODS}

\subsection{Plant Material}

The Alchemilla species studied are $A$. orthotricha Rothm., $A$. erzincanensis Pawl., $A$. hirtipedicellata Juz., $A$. mollis (Buser) Rothm., $A$. persica Rothm., $A$. oriturcica Pawl., $A$. sintenisii Rothm., $A$. barbatiflora Juz, $A$. cimilensis Kalh., $A$. hemsinica Kalh., $A$. porrectidens Juz. from ser. Elatae, $A$. sericata Reichb., $A$. erytropoda Juz., $A$. lithophila Juz. from ser. Pubescentes, $A$. rizensis from ser. Sericeae, $A$. dura Buser, $A$. ancerensis Kalh., A. retinervis Buser from ser. Calycinae and $A$. valdehirsuta Buser, $A$. monticola Opiz, A. compactilis Juz., A. daghestanica Juz., $A$. pseudocartalinica Juz.from ser. Vulgares collected in North Anatolia in July and August of 1996. Identifications of the specimens were made with the aid of Flora of Turkey (Pawlowski and Walters, 1972), Flora of the USSR (Juzepczuk, 1941), Flora Iranica (Fröhner, 1969), Flora Europaea (Walters and Pawlowski, 1968) and Flora of Sweden (Hess et al., 1970). Specimens are kept in the Herbarium of Karadeniz Technical University, Department of Biology (KTUB). Leaves were dried overnight under vacuum at $60{ }^{\circ} \mathrm{C}$ and kept in a freezer $\left(-20^{\circ} \mathrm{C}\right)$ until extraction.

\subsection{Lipid Extraction and Preparation of Fatty Acid Methyl Esters}

Leaves were ground into a fine powder with a Waring blender and lipids were extracted with chloroform:methanol $(2: 1, \mathrm{v}: \mathrm{v})$ according to Bligh and Dyer (1959). The extract was filtered through a sintered funnel, followed by 4 washes with the solvent mixture. The pooled filtrate was subjected to Folch washing (Folch et al., 1957) using 0.9\% sodium chloride one fourth of the total filtrate to remove water-soluble impurities. The chloroform: methanol phase was subsequently evaporated to near dryness in a rotary vacuum evaporator, and the residue was again dissolved in $10 \mathrm{ml}$ of chloroform. A suitable aliquot was evaporated to dryness to determine the oil content by weighting. The lipids were saponified and fatty acids methylated according to Folch et al. (1957). Fatty acid methyl esters were prepared from three independent lipid extraction of leaf samples.

\subsection{Gas Chromatography Analysis of Fatty Acid Methyl Esters}

The methylated sample solutions were analyzed with a Varian 3300 gas chromatograph (GC) equipped with a flame ionization detector (FID) and a $\mathrm{HP}-1$ silica capillary column (crosslinked methyl silicone gum, $0.17 \mu \mathrm{m}$ film thickness, $25 \mathrm{~m}, 0.32 \mathrm{~mm}$ i.d.). Hydrogen was used as the carrier gas at a flow rate of ca. $40 \mathrm{~cm} / \mathrm{s}$, and the column oven temperature was programmed from $100^{\circ} \mathrm{C}$ to $290^{\circ} \mathrm{C}$ at $6{ }^{\circ} \mathrm{C} / \mathrm{min}$ heating rate. The injector and detector temperatures were held at $260^{\circ} \mathrm{C}$ and $290{ }^{\circ} \mathrm{C}$, respectively. Peak areas were measured with a Merck-Hitachi D-2000 integrator. Peaks were identified by the comparison with standard fatty acid methyl esters. Methyl heptadecanoate (Me-17:0) was used as internal standard. The $C$ 18:2 and $C$ 18:3 acids are overlapped with the HP-1 column and not properly separated, so their amounts were calculated as their sum.

\section{RESULTS AND DISCUSSION}

Leaf fatty acid compositions of total lipids in 23 species from five series of the genus Alchemilla $\mathrm{L}$. are presented in Table I. The presence of saturated $C$ 12:0, C 14:0, C 16:0, C 18:0, C 20:0, C 22:0, C 24:0, C 26:0 and $C 28: 0$ and unsaturated $C$ 16:1, $C$ 18:1, $C$ 18:2 and $C$ 18:3 were determined, with $C$ 16:0, $C$ 18:0, $C$ 18:2 and $C 18: 3$ as the major fatty acids.

The chemistry confirms the morphological differences. Thus, for the unsaturated $C 18: 2$ and $C 18: 3$ acids, the values varied between 50.82 and $78.34 \%$ for ser. Elatae, between 49.01 and $68.74 \%$ for ser. Pubescentes, between 51.34 and $73.94 \%$ for ser. Calycinae, and between 65.44 and $74.88 \%$ for ser. Vulgares. The values for saturated C $16: 0$ acid, as a third major fatty acid, varied between 11.78 and $25.92 \%$ for ser. Elatae, between 21 and $26.51 \%$ for ser. Pubescentes, between 15.97 and $20.20 \%$ for ser. Calycinae, between 14.78 and $24.30 \%$ for ser. Vulgares. The C 20:0, C 22:0, C 24:0 and C 28:0 acids were not detected in most of these species, and the $C$ 18:1 acid was determined in trace amounts $(<0.1 \%)$.

The content of $C 18: 1$ acid was determined in trace amount in some species of ser. Elatae and Pubescentes, except $A$. erzincanensis (9.25\%). In ser. Calycinae and Vulgares, the $C 18: 1$ acid content was found in significant levels especially in $A$. retinervis (16.19\%) and $A$. erzincanensis (9.25\%). However, the highest content of $C 14: 0$ acid was found in A. lithophila (ser. Pubescentes) and $A$. retinervis. The $C 18: 0$ acid has its highest content in A. erzincanensis $(9.43 \%), A$. sericata $(7.47 \%), A$. lithophila (8.87\%), A. dura (4.69\%), A. retinervis $(5.32 \%), A$. valdehirsuta $(4.80 \%)$ and $A$. daghestanica $(4.92 \%)$. 
Table I

Fatty acid composition (\% total) of Alchemilla species collected from Northeast Anatolia (Turkey)

\begin{tabular}{|c|c|c|c|c|c|c|c|c|c|c|c|c|}
\hline \multirow{2}{*}{ Species } & \multicolumn{12}{|c|}{ Fatty acids (\%) } \\
\hline & $12: 0$ & $14: 0$ & $16: 0$ & $16: 1$ & $18: 0$ & 18:1 & $18: 2+18: 3$ & $20: 0$ & 22:0 & $24: 0$ & $26: 0$ & 28:0 \\
\hline
\end{tabular}

Ser. Elatae

A. orthotricha Rotm.

A. erzincanensis Pawl.

A. hirtipedicellata Juz.

A. mollis (Buser) Rothm.

A. persica Rothm.

A. oriturcica Pawl.

A. sintenisii Rothm.

A. barbatiflora Juz.

A. cimilensis Kalh.

A. hemsinica Kalh

A. porrectidens Juz.

\section{Ser. Pubescentes}

A. sericata Reichb.

A. erytropoda Juz.

A. lithophila Juz.

\section{Ser. Sericeae}

A. rizensis $\mathrm{Pawl}$.

\section{Ser. Calycinae}

\section{A. dura Buser}

A. ancerensis Kalh.

A. retinervis Buser

Ser. Vulgares

A. valdehirsuta Buser

A. monticola Opiz

A. compactilis Juz.

A. daghestanica Juz.

A. pseudocartalinica Juz.

$\begin{array}{ccccccccccccc}0.25 & 1.28 & 14.48 & 0.81 & 4.87 & \text { tr. } & 73.51 & 1.91 & 1.98 & 0.92 & \text { ** }^{* *} & - \\ - & 4.58 & 25.92 & - & 9.43 & 9.25 & 50.82 & - & - & - & - & - \\ 0.48 & 1.39 & 12.94 & 0.53 & 3.51 & \text { tr. } & 78.34 & 1.06 & 1.11 & 0.64 & - & - \\ 0.07 & 1.29 & 17.28 & 1.02 & 4.79 & \text { tr. } & 71.41 & 1.71 & 1.51 & 0.95 & - & - \\ 0.20 & 1.20 & 18.59 & 1.12 & 4.13 & \text { tr. } & 73.22 & 0.80 & 0.54 & 0.19 & - & - \\ 0.14 & 0.91 & 11.78 & 0.82 & 4.61 & \text { tr. } & 74.95 & 2.09 & 3.46 & 1.25 & - & - \\ 0.26 & 2.19 & 17.83 & 1.02 & 4.52 & \text { tr. } & 71.24 & 1.28 & 1.07 & 0.59 & - & - \\ - & 1.34 & 16.25 & 0.99 & 5.93 & \text { tr. } & 72.18 & 1.44 & 1.18 & 0.71 & - & - \\ - & 1.20 & 17.52 & \text { tr. } & 3.89 & 1.08 & 74.19 & 0.68 & 0.34 & 0.37 & 0.38 & 0.33 \\ - & 1.18 & 15.49 & \text { tr. } & 4.19 & 0.68 & 75.69 & 1.00 & 0.58 & 0.58 & 0.60 & - \\ - & 1.29 & 15.76 & \text { tr. } & 5.23 & 0.21 & 73.62 & 1.14 & 0.76 & 0.59 & 0.64 & 0.75\end{array}$$$
\text { - } 3.09
$$

26.51

tr. $\quad 7.47 \quad 2.63$

51.09

3.15

$0.49 \quad 2.56$

21.66

- 7.20

23.0

1.91

$2.33 \mathrm{tr}$

68.74

0.58

49.01

0.3

1.03

1.03

13.5

0.73

2.93

0.05

76.47

2.28

$0.09 \quad 1.38$

15.97

$0.67 \quad 4.69$

0.11

73.94

1.26

$-\quad 1.57$

$20.20 \quad$ tr. $\quad 3.07$

0.71

72.88

0.86

- 6.96

20.17

tr.

5.32

16.19

51.34

\begin{tabular}{cccccccccccc}
0.06 & 1.29 & 17.27 & 1.00 & 4.80 & 1.71 & 71.41 & 1.51 & 0.95 & - & - & - \\
- & 2.23 & 19.26 & tr. & 3.61 & 0.38 & 73.52 & 0.67 & 0.30 & - & - & - \\
- & 2.9 & 24.30 & tr. & 3.29 & 3.55 & 65.44 & 0.48 & - & - & - & - \\
0.10 & 1.60 & 15.49 & 1.54 & 4.92 & 0.12 & 72.01 & 1.91 & 1.47 & 0.84 & - & - \\
- & 0.82 & 14.78 & tr. & 3.44 & 2.34 & 74.58 & 0.65 & 0.49 & 0.82 & 0.01 & 0.76 \\
\hline
\end{tabular}

* tr.: trace amounts $(<0.1 \%)$.

** not detected.

The $C$ 18:2 and C 18:3 and C 16:0 acids are considered as the main fatty acids in Rosaceae family. Shorland (1963) has recognized linoleic (18:2) and oleic (18:1) acids as major acids in the seeds of Rosaceae family. The seed fatty acids of most
Rosaceae are mainly linoleic and oleic acids, with occasionally linolenic acid, and usually about $10 \%$ of saturated acids. Members of the Rosoideae (Filipendula, Geum, Rosa, Sanguisorba) produce more linolenic glycerides (from 14-47\%) (Hilditch, 1964). 
Reher (1991) investigated the seed fatty acid composition of 7 species of the Sanguisorbeae and 7 species of the Potentilleae subfamilies of Rosaceae. The content of $C 18: 3$ and $C 18: 2$ amounted together to more than $70 \%$ in 11 species. The ratio of linolenic acid to linoleic acid was shown to be significantly higher in Potentilleae (1.4 to 2.4) than in Sanguisorbeae (0.4 to 10). The C 18:1, C 18:2 and C $16: 0$ acids were also identified as the major fatty acids in the seeds of cherry laurels (Ayaz et al., 1995) and almonds (García-López et al., 1996).

Consequently, the C 18:2, C 18:3 and C 16:0 acids were identified as the main fatty acids in Alchemilla leaves as well as the seeds of most species of Rosaceae family. From a chemotaxonomic point of view, the present results suggest that fatty acid composition explains remarkable differences between species and series in the genus Alchemilla.

The highest content of $C 18: 2$ and C 18:3 acids was found for ser. Elatae, Sericeae and Calycinae, respectively. The content of $C 16: 0$ acid was generally found higher in species of ser. Pubescentes than in other series. Our results suggest that fatty acid composition C 16:0, C 18:2 and C 18:3 acids can be used as taxonomic markers in the genus Alchemilla.

\section{BIBLIOGRAPHY}

Ayaz, F. A., Reunanen, M., Küçükislamoglu, M. and Var, M. (1995).- «Seed fatty acid composition in wild form and cultivars of Laurocerasus officinalis Roem».-Pak. J. Bot., 27, 305-308.

Baytop, T. (1984).- «Türkiye'de Bitkiler ile Tedavi (Geçmiste ve Bugün)".- N. ${ }^{0}:$ 3255, Ecz. Fak. N. ${ }^{\circ}: 40$, p. 417, Istanbul Universitesi Yayinlari, Istanbul.

Bligh, E. G. and Dyer, N. J. (1959).— «A rapid method for total lipid extraction and purification».-Can. J. Biochem. Physiol., 37, 911-917.

Folch, J. L. and Sloane-Stanley, G. H. (1957).- «A simple method for the isolation and purification of total lipids from animal tissues".-J. Biol. Chem., 226, 497-509.

Fröhner, S. (1969).- «Alchemilla L.».-Rechinger, K. H., Flora Iranica, Vol 66, 124-147. Graz. Akad. Druck-u, Verlagsant.

García-López, C., Grane-Teruel, N. and BerenguerNavarro, V. (1996). - «Major fatty acid composition of
19 almond cultivats of different origins. A chemometric approach».-J. Agric. Food Chem., 44, 1751-1755.

Hayirlioglu-Ayaz, S. (1997).- «Morphological and Cytotaxonomical examination of Alchemilla species distributed in east Black Sea Region".-Karadeniz Technical University, Department, Biology, Trabzon, Turkey.

Hayirlioglu, S. and Beyazoglu, B. (1997)._-Five new Alchemilla(Rosaceae) records for the Flora of Turkey".-Tr. J. Bot. 21, 309-312.

Hayirlioglu-Ayaz, S. and Beyazoglu, B. (1997).- «A new species of Alchemilla L. (Rosaceae) from Turkey».Ann. Bot. Fennici 34, 109-113.

Hegnauer, R. (1989).- «Chemotaxonomie der Pflanzen».Vol. VII, 611-612, Birkhauser, Basel.

Hess, H. E., Landolt, E. and Hirzel, R. (1970)."Alchemilla L.».-Flora der Schweiz Band 2, 317-364, Birkhauser Verlag, Basel.

Harborne, J. B. and Turner, B. L. (1984).- «Plant Chemosystematics».-Academic Press. London.

Hilditch, T. P. (1964). — «In The Chemical Constitution of Natural Fats".-4 th Edn., Chapmann-Hall, London, 243.

Izmailow, R. (1981)._- «aryological studies in species of Alchemilla $\mathrm{L}$. from the Calycinae Bus. (Section Brevicaulon Rothm)».-Acta Biol. Cracovensia Ser. Bot. 23, 117-130.

Juzepchuk, S. W. (1941).- «Alchemilla L.»-Flora USSR. Izd. Akad. Nauk. S.S.S.R. Vol. 10, 289-410. Moskva-Leningrad.

Kalheber, H. (1994).- «The genus Alchemilla L. (Rosaceae) in the Turkish Vilayet Rize (northeastern Anatolia) with some remarks on distribution of the genus in other parts of northern Anatolia".Sendtnera, 2, 389-430.

Pawlowski, B. and Walter, S. M. (1972).-«Alchemilla L.".-Flora of Turkey and the East Aegean Islands. Vol. 4, 80-104. Edinburgh University Press, Edinburgh.

Reher, G. (1991). - «The triterpenoid and fatty acid pattern of several genera of the Rosoideae (Rosaceae). Planta Med., 57, 76-77.

Shorland, F. B. (1963).- «The Distribution of Fatty Acids in Plant Lipids".-Chemical Plant Taxonomy (Swain, T., ed.), 235-311, Academic Press, New York.

Walters, S. M. and Pawlowski, B. (1968).- «Alchemilla L.".-Flora Europaea, Vol. 2, 48-64. Cambridge University Press. 